\title{
Lumen
}

Selected Proceedings from the Canadian Society for Eighteenth-Century Studies

\section{Graphs, Maps, and Digital Topographies: Visualizing The Dunciad as Heterotopia}

\section{Allison Muri}

Volume 30, 2011

URI : https://id.erudit.org/iderudit/1007717ar

DOI : https://doi.org/10.7202/1007717ar

Aller au sommaire du numéro

Éditeur(s)

Canadian Society for Eighteenth-Century Studies / Société canadienne d'étude du dix-huitième siècle

ISSN

1209-3696 (imprimé)

1927-8284 (numérique)

Découvrir la revue

Citer cet article

Muri, A. (2011). Graphs, Maps, and Digital Topographies: Visualizing The Dunciad as Heterotopia. Lumen, 30, 79-98. https://doi.org/10.7202/1007717ar

Copyright @ Canadian Society for Eighteenth-Century Studies / Sociéte canadienne d'étude du dix-huitième siècle, 2011
Ce document est protégé par la loi sur le droit d'auteur. L'utilisation des services d'Érudit (y compris la reproduction) est assujettie à sa politique d'utilisation que vous pouvez consulter en ligne.

https://apropos.erudit.org/fr/usagers/politique-dutilisation/ 


\section{Graphs, Maps, and Digital Topographies: Visualizing The Dunciad as Heterotopia}

Hence springs each weekly muse, the living boast

Of $C-l$ 's chaste press, and $L-t^{\prime}$ 's rubric post;

Hence hymning Tyburn's elegiac lay,

Hence the soft sing-song on Cecilia's day,

Sepulchral lyes our holy walls to grace,

And New-year Odes, and all the Grubstreet race.

'Twas here in clouded majesty she shone ...

Alexander Pope, The Dunciad I.27-33

when strait I might discry,

The Quintescence of Grub street, well distild

Through Cripplegate in a contagious Map.

John Taylor, All The Workes of Iohn Taylor the Water-Poet, $2^{1}$

"Where was Grub Street?" Pat Rogers asked in his landmark study of "the topography of Dulness" in eighteenth-century London. ${ }^{2}$ We might well ask where is the "here" where Dulness shines in the epigraph above, and we would find the same answers that Rogers did: topographically, Grub Street and Dulness can be situated at particu-

1 John Taylor, All the workes of Iohn Taylor the Water-Poet (Charlottesville: University of Virginia Library), <http:/ /xtf.lib.virginia.edu/xtf/view?docId=chadwyck_ep/ uvaGenText/tei/chep_1.1964.xml>.

2 Pat Rogers, Grub Street: Studies in a Subculture (London: Methuen \& Company, 1972), 18. 
lar coordinates of the city, with particular social and material histories; metaphorically, they are everywhere throughout the city, a permeating fog of intellectual turpitude and pedantry. If we were to construct a digital map of this literary territory, what could we discover that we cannot already visualize in the schematic maps provided by Aubrey Williams $^{3}$ in 1955, Rogers in 1972, or Valerie Rumbold ${ }^{4}$ in 1999? The following commentary starts from the position that digital scholarship and editing can provide enriched readings of literary texts through visualizations that extend beyond what is possible in print. This activity entails the "distant reading," proposed by Franco Moretti, a method that involves schematic representations such as graphs and trees, statistical analysis, and mapping of texts as opposed to traditional literary "close" readings. This activity does not eliminate the possibility of close reading, since digital displays of both high-resolution facsimile and diplomatic editions also provide the opportunity for studying texts, intertextual references, and cultural relationships that inform traditional scholarship. As Jerome McGann has already argued, a digital archive of literary and artistic works can encompass a social text, a vast edition reflecting the social-text editorial procedure proposed by D. F. McKenzie. ${ }^{5}$ The digital edition displays both texts as "linguistic forms" and books as "social events" umentary record not only of how literary works might have existed as words and ideas in their time, but also of innumerable intertextual relationships, and of material evidence such as the typography, layout, and illustrations of these texts, visualizations of how/where/when they were transmitted, or how they constructed and were constructed by a material world of trade and commerce, of news, even of architecture, buildings, streets, and alleys. As McGann comments, we can

3 Aubrey Williams, Pope's "Dunciad": A Study of Its Meaning (Baton Rouge: Louisiana State University Press, 1955).

4 Valerie Rumbold, ed., The Dunciad: In Four Books (New York: Longman, 1999).

5 D. F. McKenzie, Bibliography and the Sociology of Texts (Cambridge: Cambridge University Press, 1999).

6 Jerome McGann, "From Text to Work: Digital Tools and the Emergence of the Social Text," Romanticism on the Net 41-42 (February-May 2006), <http:/ /www. erudit.org/revue/ron/2006/v/n41-42/013153ar.html>; see also Dino Buzzetti and Jerome McGann, "Electronic Textual Editing: Critical Editing in a Digital Horizon," Electronic Textual Editing, ed. Lou Burnard, Katherine O'Brien O'Keeffe, and John Unsworth (New York: Modern Language Association of America, 2006), 53-73. 
now create "editorial machines capable of generating on demand multiple textual formations - eclectic, facsimile, reading, genetic - that can all be subjected to multiple kinds of transformational analyses." With the arrival of digital scholarship, we are presented with new possibilities and an opportunity to expand the possibilities for the visualization of eighteenth-century London and its society of letters. ${ }^{7}$ I have written elsewhere of my Grub Street Project to create a system to map and thereby visualize the material networks of print and other trades in London in the long eighteenth century, from the Restoration through the Georgian era. ${ }^{8}$

Franco Moretti's "very simple question about literary maps," that is, "what exactly do they do? What do they do that cannot be done with words ... ?" has yet, I think, to be fully explored. Moretti asks, "Do maps add anything, to our knowledge of literature?"' ${ }^{\prime 9}$ Clearly, I think they do, as they have done long before digitization. Beyond this, the incorporation of high-resolution full-colour facsimiles of maps, prints and books with databases of contextual material will transform the way we visualize and research historical literature such as The Dunciad of $1728^{10}$ and Dunciad Variorum of $1729 .{ }^{11}$

To begin, then: where was Grub Street? In terms of the real place, a textual description such as John Strype's in 1720 is opaque: situated in Cripplegate Ward, he wrote, the street is "very long, coming out of Forestreet, and running, Northwards, into Chiswel street; but some small part, to wit, from Sun Alley to Chiswel street, is not in the Ward, but in the Liberty of Finsbury. This Street, taking in the whole, is but indifferent, as to its Houses and Inhabitants; and sufficiently pestered with

7 Some illustrative figures are available in this article; for a larger set of visualizations in full colour, see <http://grubstreetproject.net/alexanderpope/dunciad1728-9>.

8 Allison Muri, "The Technology and Future of the Book: What a Digital 'Grub Street' Can Tell Us About Communications, Commerce, and Creativity," in Producing the Eighteenth-Century Book: Writers and Publishers in England, 1650-1800, ed. Laura Runge and Pat Rogers (Newark: University of Delaware Press, 2009), 23550 .

9 Franco Moretti, Graphs, Maps, Trees: Abstract Models for a Literary History (London: Verso, 2005), 35.

10 David L. Vander Meulen, Pope's Dunciad of 1728: A History and Facsimile (Charlottesville and London: University Press of Virginia, 1991), hereafter citied as Dunciad.

11 Allison Muri, Pope's Dunciad Variorum of 1729: A Digital Facsimile, $<$ http://grubstreetproject.net/alexanderpope/dunciad1729>, hereafter cited as Dunciad Variorum. 
Courts and Alleys ..."12 More helpful for visualizing the poem's topography, Strype's Survey of London also provides prints that can illustrate the locations of the dunces' race in Fleet Street, or Rag Fair where Dulness was seated when The Dunciad was first published in 1728 [figure 1]. Unlike printed illustrations, where options for including high-resolution full-colour images are limited by financial considerations, a digital edition could also show a contemporary view of where the Goddess was seated at Bedlam near Grub Street in the 1743 Dunciad, in John Rocque's Survey of the Cities of London and Westminster (1746); readers could also view these sites decades after Pope's death but in greater detail, in Richard Horwood's Plan of the Cities of London and Westminster (1792-1799). Readers could visualize the poem by following the dunces in their games from St. Mary le Strand, to Curll's shop (opposite St. Dunstan's Church in Fleet Street or opposite Catherine Street in the Strand, depending on when Pope wrote this segment ${ }^{13}$ ); then to Bridewell, Fleet Ditch, and through Ludgate into the city on an eighteenthcentury map [figure 1]. One could link to images of or maps showing Smithfield where, as Pope's note informs his readers, "Bartholomew Fair was kept, whose shews, machines, and Dramatical entertainments, formerly agreeable only to the taste of the Rabble, were, by the Hero of this Poem and others of equal genius, brought to the Theatres of Covent-Garden, Lincolns-Inn-Fields, and the Hay-market, to be the reigning Pleasures of the Court and Town" (Dunciad Variorum, note for I.2) [figure 2]. One could see Strype's image of Bedlam Hospital as Robert Hooke's orderly "palace beautiful" contrasted with Hogarth's heterotopic representation of this hospital for the mad. We could map not

12 John Strype and John Stowe, A Survey of the Cities of London and Westminster vol. 1 (London: printed for A. Churchill, J. Knapton, etc., 1720), 93.

13 David Vander Meulen suggests that Pope may have written a "progenitor of the full Dunciad," around 1720 (8). Paul Baines and Pat Rogers indicate that Curll's shop was opposite St. Dunstan's Curch, Fleet Street, from 1709 to 1718; he moved to a house "next the Temple Coffee House in Fleet Street" at the end of 1718, which may have been the same shop. Curll was briefly in Paternoster Row in 1720 and moved to new premises in the Strand in fall of 1720 (Paul Baines and Pat Rogers, Edmund Curll, Bookseller. New York: Oxford University Press, 2007, 145). One could speculate that the composition of the passage depicting the race with Curll slipping in his Corinna's "evening cates" predated his shop's move from Fleet Street since the race would more sensibly remain on that street, logically proceeding in one direction from St. Mary le Strand eastward toward Fleet Ditch, Bridewell, and Ludgate, rather than looping west from St. Mary le Strand to Curll's shop in the Strand before proceeding eastward again (for the locations of Curll's shops, see figure 2). 
only the fiction of print culture that Pope creates, but also the historical print culture.

We could do all this, but what might we see? What new discoveries could be made through this process? How would it carry the argument further? All these remnants of material culture can be made visible online, and they can lend some life to the space of The Dunciad, but as Rogers remarked, "The 'map' is finally only a palimpsest. For the Grub Street which shows up there as an outlying enclave is no more than a shadow on the wall of the cave. The real Grub Street is elsewhere: an outlying enclave in the metropolis of letters." ${ }^{14}$ How valuable is mapping, when "Grubstreet" is metonym for literary hacks and crass commercial print culture, or "Bedlam" for madness, how valuable when "Dulness" is both character and the nation's spiritual state of "clouded majesty," "cloud-compelling," folly spread "o'er the land and deep"? Does seeing the locations of the booksellers and authors implicated in the Dunciad illuminate our reading of the poem? My suggestion is that maps, along with the dynamic display of graphs and archival printed materials can help us to investigate how that space, and its literary and social networks, as well as material trade networks, help us to see what Pope and his readers saw in that figure of Dulness that is impersonated in localizable points such as Bedlam, Fleet Ditch, or St. Mary le Strand in Fleet Street but that also lies like a mist over the entire city. Moreover, they can illuminate Pope's self-representation in the topography of dullness from which he, adopting a voice of omniscience from far above the excremental mire, excludes himself after the opening defense of "Mr. Pope's integrity"15 in "The Publisher to the Reader."

I start from the premise that, in order to visualize the topography of eighteenth-century print culture and Letters, we are best served by viewing and mapping eighteenth-century spaces as they were represented in the eighteenth century, especially, Strype's maps published in 1720 and to some extent Horwood's more detailed map from the close of the century. What I am discussing, then, is in some ways an issue of editorial theory examined though the lens of the digital map: a process of creating a scholarly text that represents both the "real" eighteenthcentury space and its representations in the imaginative spaces of fiction and poetry.

The process of mapping Pope's London is to read The Dunciad as a network of literary communications, ideas, and physical-spatial rela- 
tionships, to visualize it as a sort of countersite represented by maps of "the real" but absolutely different from those sites (which are reflected in the poem as imaginative vitriol, literary allusions, metaphor and ambiguity). Pope's world of dunces utterly embedded in the streets of London is a virtual space, a mirror of the world, in which he reconstitutes himself as victim and as judge, while simultaneously eliminating himself from the streets. Brean Hammond was first to suggest that The Dunciad could be read as "the imaginative representation of the Popean heterotopia," ${ }^{16}$ and here I will follow his lead. Foucault defined heterotopias and utopias as having "the curious property of being in relation with all the other sites, but in such a way as to suspect, neutralize, or invert the set of relations that they happen to designate, mirror, or reflect. These spaces, as it were ... are linked with all the others, which however contradict all the other sites." In opposition to utopias which were "fundamentally unreal spaces," Foucault suggested heterotopias are real locales that function "like counter-sites, a kind of effectively enacted Utopia in which the real sites, all the other real sites that can be found within the culture, are simultaneously represented, contested, and inverted." Places of this kind, he noted, are "outside of all places, even though it may be possible to indicate their location in reality."17

To map Pope's heterotopia of dulness, then, requires a visualization of the city and its book trades contrasted with the mirror or countersites presented in the poem. The first edition of The Dunciad, beginning with the words "Book[s] and the man"18 situates its initial focus on the marketplace of literature, juxtaposing books in the first line with "Smithfield muses" in the second. In the 1728 Dunciad (I.17) and 1729 Dunciad Variorum (I.27), Pope situates the Temple of Dulness in Rag Fair in the east, outside of the City of London (figure 1). ${ }^{19}$ Rosemary Lane passed through the impoverished St. Botolph Aldgate parish at the eastern boundary of the City of London, and can be seen as repre-

16 Brean Hammond, "The Dunciad and the City: Pope and Heterotopia," Studies in the Literary Imagination 38, no. 1 (2005): 231.

17 Michel Foucault and Jay Miskowiec (trans.), “Of Other Spaces,” Diacritics 16, no. 1 (1986): 24.

18 The edition reproduced in facsimile by Vander Meulen is the octavo that misprinted the first line as "Book and the man."

19 Strype defines four parts of the City of London and Westminster in 1720: the City of London within the walls and freedom, inhabited by "wealthy Merchants and Tradesmen"; the City or Liberty of Westminster and adjacent parts, the part beyond the Tower (including East Smithfield), and Southwark (Strype, vol. 2,1). 
senting a liminal thoroughfare from the relatively wealthy City and the poorer areas of Middlesex. Rag Fair emphasizes the book trade's market economy: as Pope tells his readers in the Variorum, this was "a place near the Tower of London, where old cloaths and frippery are sold", ${ }^{20}$ and as Pat Rogers explains more graphically, it was "a place infamous for crime, prostitution, poverty and cheap secondhand trading. ${ }^{\prime 21}$ The association of rags with paper-making would also imply the filth and poverty, not to mention the cheapness of the very pages that held the imprints of Dulness. One contemporary of Pope, describing the diseases of "Mechanicks and Tradesmen," included those who "gather Rags, for making Paper, which send forth noisome Smells and Steams, especially such as are made of foul Linnen, or of Beds, on which People have died of Distempers." 22 Ned Ward described the street as a "Savoury place which, in Ridicule of Fragrant Fumes that arise from Musty Rotten old Rags, and Burnt Old Shoes is call'd by the sweet Name of RosemaryLane." It was a place where a "Tatter'd Multitude" assembled every day:

where all the Rag-pickers about Town ... have recourse, to sell their Commodities, to Cow-Cross Merchants, Long-Lane Sharpers, and other Brokers, who were as busy in Raking into their Dunghills of old Shreds and Patches, and examining their Wardrobes of decay'd Coats, Breeches, Gowns, and Petticoats, as so many Cocks upon a pile of Horse-Dung, Scraping about the Filth to find an Oat worth Picking at; or like a Parsons Hogs on a Monday Morning, routing about a Church-yard to find a S- nce worth biting at. ${ }^{23}$

Notably, the imperial seat of fools in Rag Fair and the beginning of the games at St. Mary le Strand represent areas beyond the reach of Guildhall and the legal limits of the City and its Liberties.

If the first version of "Smithfield muses" in 1728 referred to East Smithfield outside of the City walls and freedom where we find Rosemary Lane, then the image of the market, of poverty, and of exclusion

\section{Dunciad Variorum, note to I.27.}

21 Rogers, Grub Street, 44.

22 Samuel Parker, George Ridpath, et al., eds. The History of the Works of the Learned 5, no. 7 (July 1703), in Eighteenth-Century Journals: A Portal to Newspapers and Periodicals (Harry Ransom Center, University of Texas), 401.

23 Ned Ward, "The London Spy," Part 2 (December 1699), in The London-Spy Compleat. In Eighteen Parts (London: printed for, and by J. How, and sold by Eliphal Jaye, 1700), 9 . 
from the wealthy City would have been relevant. The poverty of that region seems, however, to have served a less powerful signifier for the decay of literature than the heterotopia Pope constructed of Grub Street, Bedlam, and West Smithfield inside the City Liberties. Indeed, specifying the location of the Smithfield muses in West Smithfield in the 1729 Variorum edition, and moving Dulness's sacred dome from Rosemary Lane to Bedlam in the 1743 Dunciad in Four Books, reinforces a damning countersite for the topography of print trades in and around the City. Associating authorial muses with Bartholomew Fair and its raucous performances of jesters, dancers and tumblers effectively demoted authorial genius to a commerce of crass entertainment: Ned Ward for example had described the seesaw of conscience "between Pride and Profit" in an actor considering whether it is preferable to have the "Honourable Title of one of his Majesties Servants" or "BartholomewFair-Player," and choosing to play the fool at the fair for more money. ${ }^{24}$ As Pope would have it in 1729 and subsequent editions, these amusements that so basely prostitute artists, formerly agreeable only to the "taste of the Rabble," had been transplanted out of the City and moved westward, via the "Theatres at Covent-Garden, Lincoln's-Inn-Fields, and the Hay Market," to descend, finally, upon the polite society of "the Court and Town" in Westminster. ${ }^{25}$ It is this action, or progress of Dulness, that The Dunciad is presumed to detail.

From Rag Fair, then, outside the City, the queen and her dunces head to the western boundary of the City, as described by Martinus Scriblerus's helpful note in the Variorum of 1729 (note to II.258). Specifically, the games begin at the church of St. Mary le Strand - just beyond the Temple Bar at the extremity of the City's Liberties and marking the border between London and Westminster. The games continue to the east, concluding at the end of Book II with the participants passing through Ludgate, and putting one another to sleep just inside the wall, close to Stationers Hall. Dulness and her newly anointed King are returned to the Temple of the Goddess at the opening of Book III, presumably back at Rag Fair in Rosemary Lane where the "imperial seat of fools" and Dulness's "sacred Dome" is located. ${ }^{26}$

The spatial tension Pope creates with this movement of Dulness eastward, opposite to the supposed movement westward to the Court 
and Town, has inspired numerous interpretations of Pope's intentions. Aubrey Williams in 1955 argued that the situation of the games' commencement at St. Mary le Strand, "just beyond the western boundary of the City ... is highly significant": the "exact geography of the games seems partly determined by the fact that the Strand and Drury Lane were the actual sites of many printing-houses and theatres, and so could mark the encroachment of literary dulness on Westminster." ${ }^{27}$ Alvin Kernan, writing a few years later in 1962, agreed: as Williams demonstrated, he wrote, the poem's action moving west from Smithfield to "the ear of Kings" suggests "the corruption of taste and the translation of vulgarity from the City to the Court, from the center of commerce to the polite world. ${ }^{\prime 28}$ In 1972, however, Pat Rogers rightly noted that the dunces, whether in Smithfield, Bedlam, Rag Fair, or Moorfields, are in fact situated outside of the old walled City, though largely within the Liberties of the City, and "cannot be simply equated with the brokers and stockjobbers, the merchants and importers, the shopkeepers and moneylenders: for the good reason that they themselves had no real stake in the life of the City." Furthermore, the journey to Fleet Ditch "was not for them (as it was for the Lord Mayor and his party) a voyage out. It was not even an aimless peregrination. It was a homecoming." ${ }^{29}$ In 1977 David Sheehan described this progress as an "inward movement" in Book II, in "exactly the opposite direction" from the polite world in Westminster "outside the limits of the City strictly defined, further and further inward, a movement of contraction and narrowing." ${ }^{30}$ Maynard Mack, on the other hand, argued in 1988 that the movement in The Dunciad is mostly "systolic" or "centrifugal," with the only exception being "when the Smithfield Muses and their admirers ... migrate, not only from all quarters of the old City and its purlieus but seemingly from all England, to the West End." ${ }^{\prime 31}$ Finally, as Brean Hammond noted in 2001, the poem's topography suggests a "struggle between the purveyors of low-brow, popular, and irrational

Williams, Pope's “Dunciad," 33-4.

28 Alvin B. Kernan, "The Dunciad and the Plot of Satire," Studies in English Literature, 1500-1900 2, no. 3 (1962): 257.

29 Rogers, Grub Street, 75-6.

30 David Sheehan, "The Movement Inward in Pope's 'Dunciad,'” Modern Language Studies 8, no. 1 (1977-1978): 34.

31 Maynard Mack, Alexander Pope: A Life (New York and London: W. W. Norton \& Company, 1985), 785-7. 
culture" and "those who wish to prevent their infiltration into respectable vicinities" as the dunces "migrate westward toward St. James's Palace and Westminster. ${ }^{\prime 32}$

In short, Pope's poem strains in two directions, and both the topography of Dulness and the "action" of the poem escape definition, thanks to Pope's own paradoxical heterotopic vision. As others have argued, Williams was taking Pope at his word rather too easily when he adopted the model of Dulness's progression out of the City toward the world of civility. Particularly if we map the action of the book trade itself, we can see that Pope's self-creation as a morally superior poet genius in opposition to the dunces relies upon a certain representation of that trade: when Pope refers to the place "where Fleetditch with disemboguing streams / Rolls the large tribute of dead dogs to Thames", ${ }^{33}$ or to "the neighbouring Fleet / (Haunt of the Muses) $)^{\prime \prime}{ }^{34}$ when he describes the dunces moving "in the Strand, thence along Fleet-street (places inhabited by Booksellers); ${ }^{35}$ when he adds emphasis by changing "thro' the gates of Lud"36 to "Thro' Lud's fam'd gates, along the well known Fleet $\ldots{ }^{\prime \prime 37}$ in 1743 , he is systematically equating Fleet Street and the nearby sewer of Fleet Ditch with the diminishment of creative values wrought by the trade of the booksellers. Pope's self-construction, then, as the voice of high-minded opposition to cultural commercialism and the decline of taste, relies on this localization of the booksellers and scribblers in this site of excrement and offal. If, however, we examine the locations where books were printed and sold, we get a somewhat different view of the participation in this marketplace by both the dunces and Pope.

Pope's fellow conspirator Lawton Gilliver, who published the 1729 Variorum, set up his shop in $1728^{38}$ close to the shops (or former shops) of Pope's featured dunces Bernard Lintot and Edmund Curll in Fleet

32 Brean Hammond, "The City in Eighteenth-Century Poetry," in The Cambridge Companion to Eighteenth-century Poetry, ed. John Sitter (Cambridge: Cambridge University Press, 2001), 94.

Dunciad, II.247-8.

Dunciad, II.381-2.

Dunciad Variorum, 120.

36 Dunciad, II.318.

37 Dunciad in Four Books, II.359.

38 David Foxon, Pope and the Early Eighteenth-Century Book Trade, Revised and edited by James McLaverty (Oxford: Clarendon Press, 1991), 107. 
Street and the Strand, a short block and a half from Temple Bar. Certainly these historical facts are somewhat circumstantial, but as I will show, the concentration of Pope's own book sales in the area next to Temple Bar at the boundary of the old City provides insights into his representations of the print trade, which were calculated to elevate his own supposedly blameless role in the rabble of "Scribblers, Booksellers, and Printers" ${ }^{\prime \prime 39}$ who were attacking his integrity. The locations of Pope's sales also indicate quite clearly his own progress westward out of the old City.

For the following analysis I am using a dataset from the English Short Title Catalogue, ${ }^{40}$ comprising records of all monographs, newspapers, and other serial items published in London in the years just before Pope's Dunciad was published. ${ }^{41}$ Filtered by year (1720-1727) and place

\section{Dunciad, iii.}

40 I am grateful to Virginia Schilling at the Center for Bibliographic Studies \& Research, University of California at Riverside, for providing this dataset.

41 The known limitations of the English Short Title Catalogue (<http:/ / estc.bl.uk/>) mean that the data I present here provides a very good general representation of London's print culture, but nevertheless the precise figures I present here must be considered somewhat imperfect and provisional. Stephen Tabor for example has noted that the ESTC provides a description of the ideal copy for each edition ("ESTC and the Bibliographical Community" The Library 8, no. 4 (2007): 367-386). Thus any notion of a precise material reality in these numbers must be qualified, though Tabor also notes the eighteenth-century records are relatively accurate. A second caveat is that for the individual authors examined here the numbers present only a general picture to demonstrate the usefulness of a statistical approach. Often the imprint information does not provide a location. Works such as Henry Plomer's A Dictionary of the Printers and Booksellers Who Were at Work in England, Scotland and Ireland from 1668 to 1725 (Oxford: Oxford University Press, 1922), the British Book Trade Index (University of Birmingham, http://www.bbti.bham. ac.uk/), book trade indexes by Ian Maxted (Exeter Working Papers in British Book Trade History. <http://bookhistory.blogspot.com>; The London Book Trades 17751800: A Preliminary Checklist of Members. Folkestone, England: Dawson, 1977), and definitive studies by James Raven ("Constructing Bookscapes: Experiments in Mapping the Sites and Activities of the London Book Trades of the Eighteenth Century" in Mappa Mundi: Mapping Culture/Mapping the World, edited by J. Murray, 35-59. University of Windsor: Working Papers in the Humanities, 2001; "London and the Central Sites of the English Book Trade" in The Cambridge History of the Book in Britain, Volume V, edited by Michael F. Suarez and Michael L. Turner, 293-308. Cambridge: Cambridge University Press, 2009; and The Business of Books: Booksellers and the English Book Trade 1450-1850. New Haven: Yale University Press, 2007) can sometimes provide corroborating evidence of a bookseller's location in a particular year, but there is more research to be done to find exact locations for all the booksellers in question. For this study, if one record in a particular year names 
of publication (London), the ESTC shows 11,928 records of imprints from the start of the decade to the end of the year prior to publication of The Dunciad on the 18th of May, 1728.

Comparing publisher / bookseller locations from 1720-27 shows an unsurprising preponderance of the book trades around St. Paul's and in Paternoster Row (St. Paul's appears in the imprint field of 908 records, while Paternoster Row appears in 1,068), with Fleet Street and the area around Temple Bar making a strong showing as well (searching for "Temple Bar" or "Temple Gate" finds 729 records - some of which of course list more than one bookseller's shop in that location). Notably, and not surprisingly, the sites occupied by Pope's fictional dunces are not noticeably saturated with the book trades. Grub Street, active in the 1600 s, by now shows no activity in the book trade. A search for Smithfield in the imprint field results in just 119 records, mostly associated with nearby Bartholomew Close. A mere 33 records are associated with Lincoln's Inn, 148 with Covent Garden, and just 30 with Hay Market.

Pope's dunces present a closer view of this scene. For example, Lewis Theobald's publications up until the publication of The Dunciad were, indeed, largely sold in Fleet Street close to the Temple Bar or Temple Gates [Figure 3]. A few of his works were sold inside the City Wall, principally Warwick Lane, but certainly Theobald represents the image Pope presents of the spread of Dulness westward. "Ear-less" Daniel Defoe, however, shows Pope's heterotopia of Dulness reflects a distorted view. The majority of Defoe's booksellers in the decade up to the publishing of The Dunciad were located within the old City Walls, and hardly scurrilous places: Paternoster Row, Warwick Lane, near Stationers' Hall, St. Paul's churchyard, and Cornhill near the Royal Exchange [Figure 4]. It is unremarkable, certainly, that Pope's world is unfaithful to the real one, but this mapping in particular shows first that the association of Dulness with Fleet Street and Fleet Ditch does not apply to this dunce, and creates one telling instance of the heterotopic tension between reality (site) and representation (countersite). Similarly, the locations of Eliza Haywood's booksellers conflicts with a representation of the marketplace of literature moving westward. A significant percentage of Haywood's publications in the years 1720-1727 were sold in the area around Temple Bar and Temple Gates, but booksellers in Pall Mall to the west and Warwick Lane are also well represented.

a bookseller's location, and another does not, or if a location is named over a span of years but is missing in a record within that timeframe, I apply that location to the record(s) where there is none named. 
These locations show Haywood's books straying from Pope's imagined centers of dulness and the sewer of Fleet Street, almost equally representing the established center of the book trade close to Stationers Hall inside the City Wall, and the new "reigning pleasures of the Court and Town. ${ }^{\prime \prime 2}$

Pope's own record shows that the booksellers marketing his books from the time of his first publication in Poetical Miscellanies, The Sixth Part (1709) to that of The Dunciad are almost wholly centered in the Temple district - where the gate out to the Strand and to Westminster is situated (largely because of his association with Lintot) [Figure 5]. Notably, as Maynard Mack explains, except for one or two pieces in other anthologies, after his first publication in Poetical Miscellanies (printed for Jacob Tonson within Grays Inn Gate), Pope never again published with Tonson. Mack suggests this was very probably "because they were 'too well matched in the driving of shrewd bargains ${ }^{\prime \prime \prime 4}$ : Pope was firmly situated in the landscape of both kinds of dunces, the booksellers driven by profit, and the writers scribbling away for the same end. Moreover, while a significant portion of his publications were sold inside the old City walls at the start of his career, in the 1720s up to the publication of The Dunciad the bulk of his works were sold near the Temple Bar or Gates in Fleet Street. ${ }^{44}$ Pope's own commercial profits squat squarely upon Corinna's evening cates.

I return now to my premise concerning digital topographies. My readers surely will have noted that I am presenting this information in print, but what I present here is of course a limited view of digital texts and visualizations, which can be dynamically generated from a database; which can connect with other collections online ranging from London Lives 1690-1800 to Eighteenth-Century Collections Online to 18thConnect; and which are not limited in terms of the space allotted by the page format, the use of colour, the number of figures, or the generation of new views with new search queries. ${ }^{45}$ Visualizing connections and connectedness (material, topographical, professional, temporal, symbolic) gives scholars an opportunity to "see" the poem

42 See <http://grubstreetproject.net/alexanderpope/dunciad1728-9>, Figure 7. Mack, Alexander Pope: A Life, 124.

44 See <http://grubstreetproject.net/alexanderpope/ dunciad1728-9>, Figure 6.

45 For some examples of digital displays, and for more complete tables of booksellers and their locations, see $<$ http://grubstreetproject.net/alexanderpope/dunciad1728-9>. 
differently than when we approach it through a printed edition. These new readings, whether dynamically generated or carefully edited and statically displayed, can heighten and consolidate older connections that we have already made at the same time as they invite newer conceptualizations. Pope's self construction in opposition to his named dunces is clearly rather hypocritical, situated as he was in the crass commercialism of the book trades expanding out of the City along with other commercial ventures encroaching upon the Strand. This claim is not particularly new, but to see the book trade of Pope and the dunces in this light suggests how powerfully motivated Pope was to remove himself from the very locale of his commercial success: he was firmly positioned in the market he so despised, and situating Lewis Theobald or Daniel Defoe or Eliza Haywood in that locale would seem to be a move to displace his own complicity, and his own marked presence, in the money-grubbing market of the book trade in Fleet Street. The power of databases and digital visualization creates a new text against which to read Pope's heterotopic vision. Digital mapping gives us, at the very least, the ability to see literary works in ways we have not yet seen them.

ALLISON MURI

University of Saskatchewan 


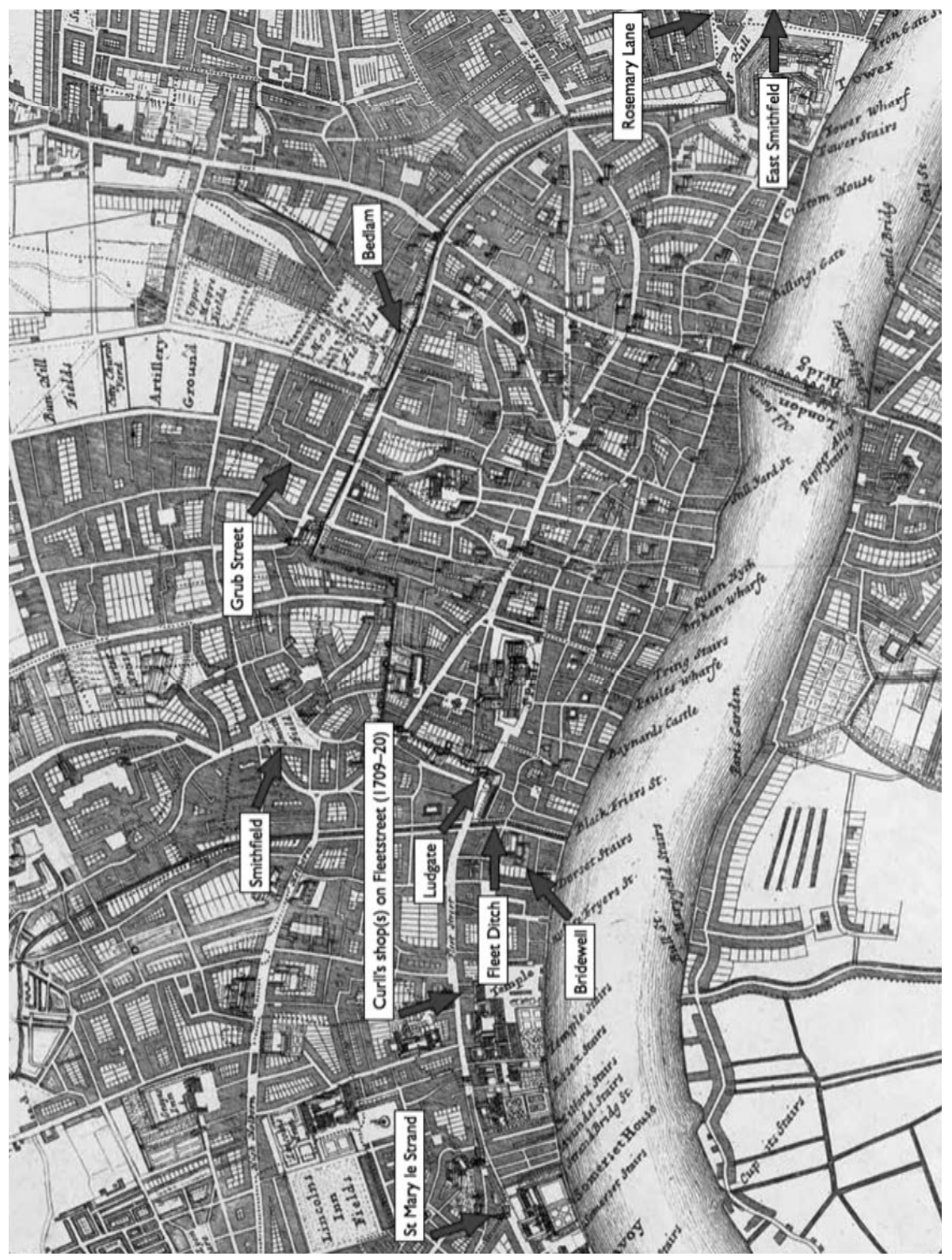

Figure 1. The topography of "all the Grubstreet race" 
94 Allison Muri

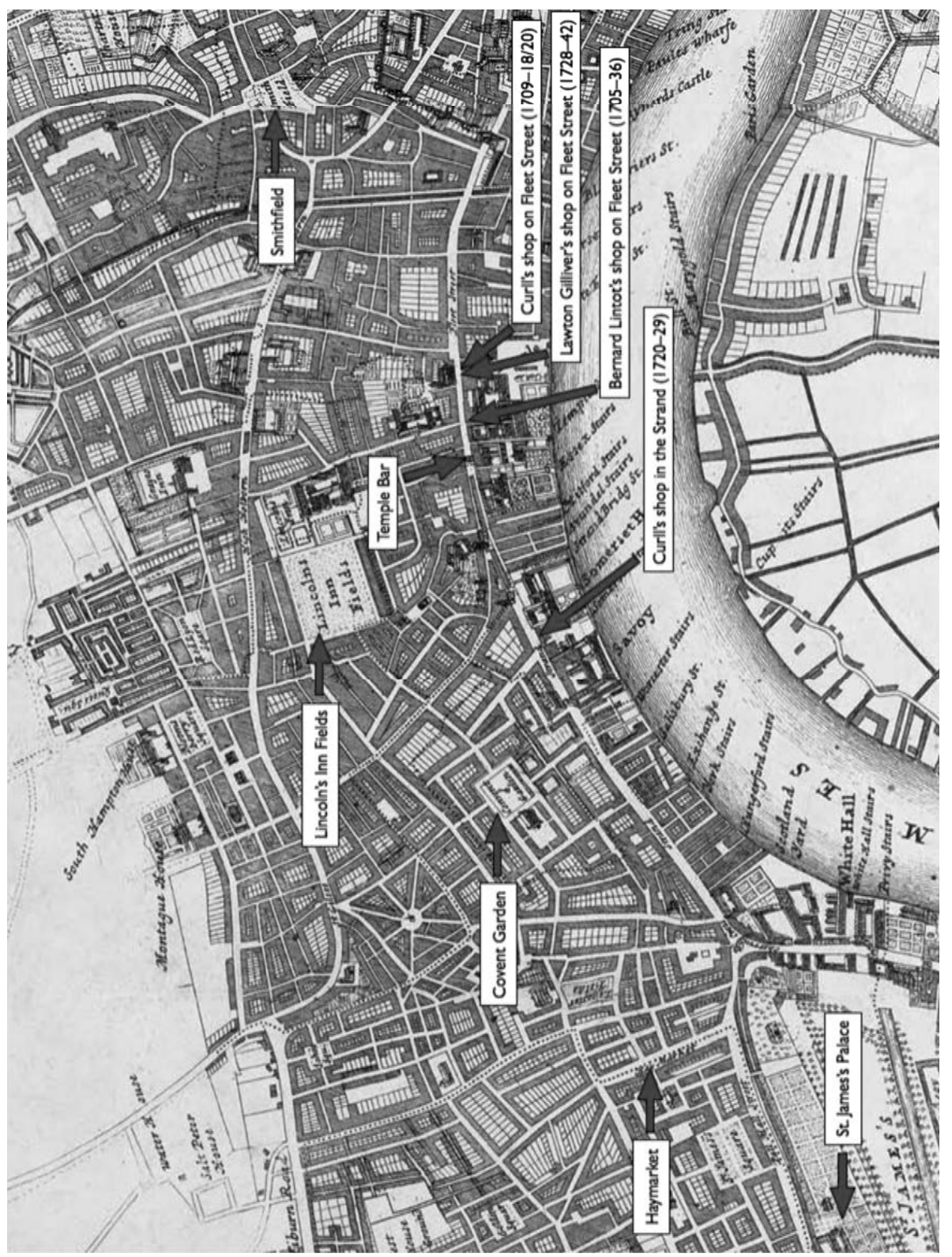

Figure 2. The "taste of the Rabble" progresses from Smithfield to become the "reigning Pleasures of the Court and Town." 


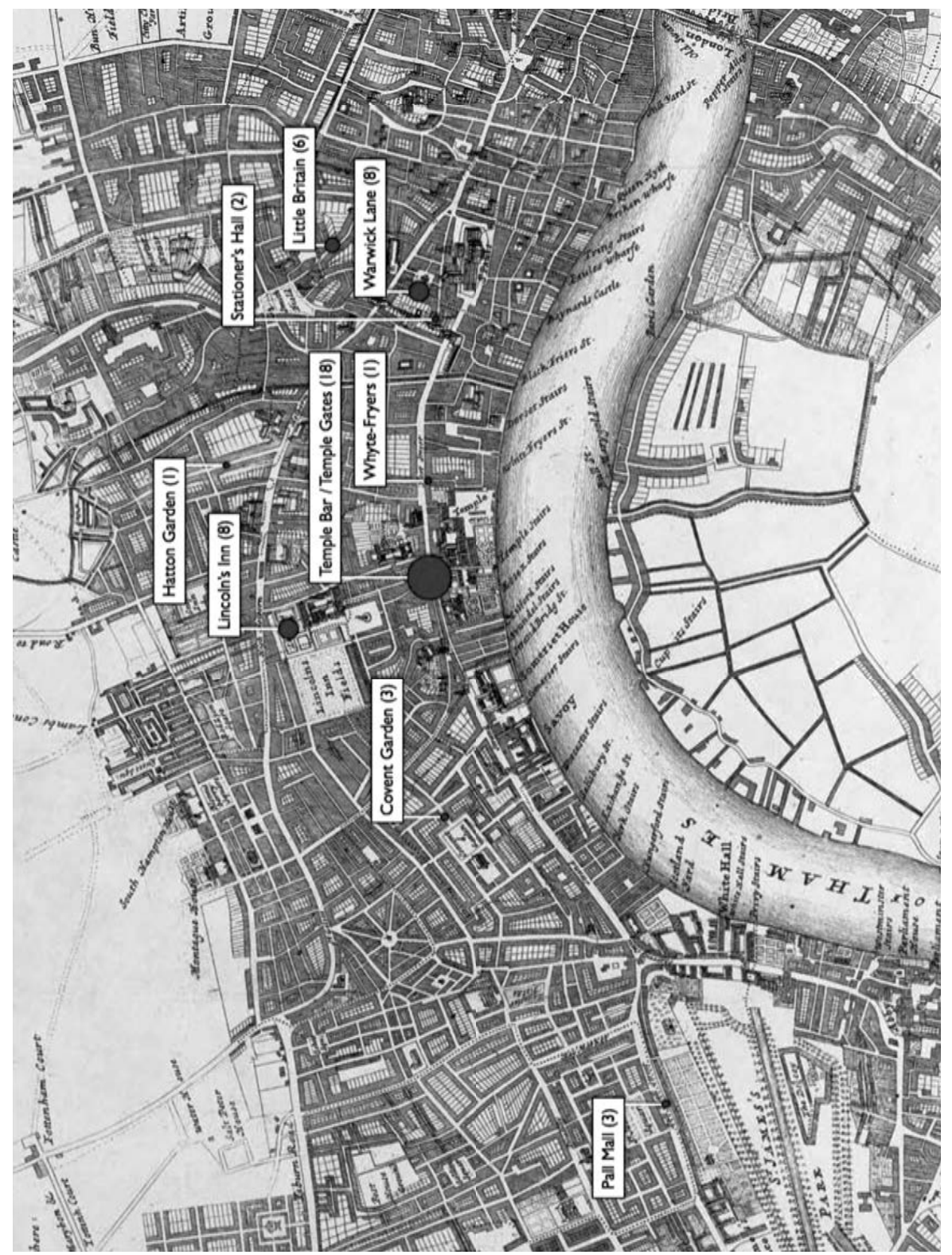

Figure 3. All of Lewis Theobald's booksellers in ESTC records up to publication of The Dunciad (1707-1727). As in a bubble chart, the area of each circle corresponds to a value (here, the number of books published or sold in a given location). 
96 Allison Muri

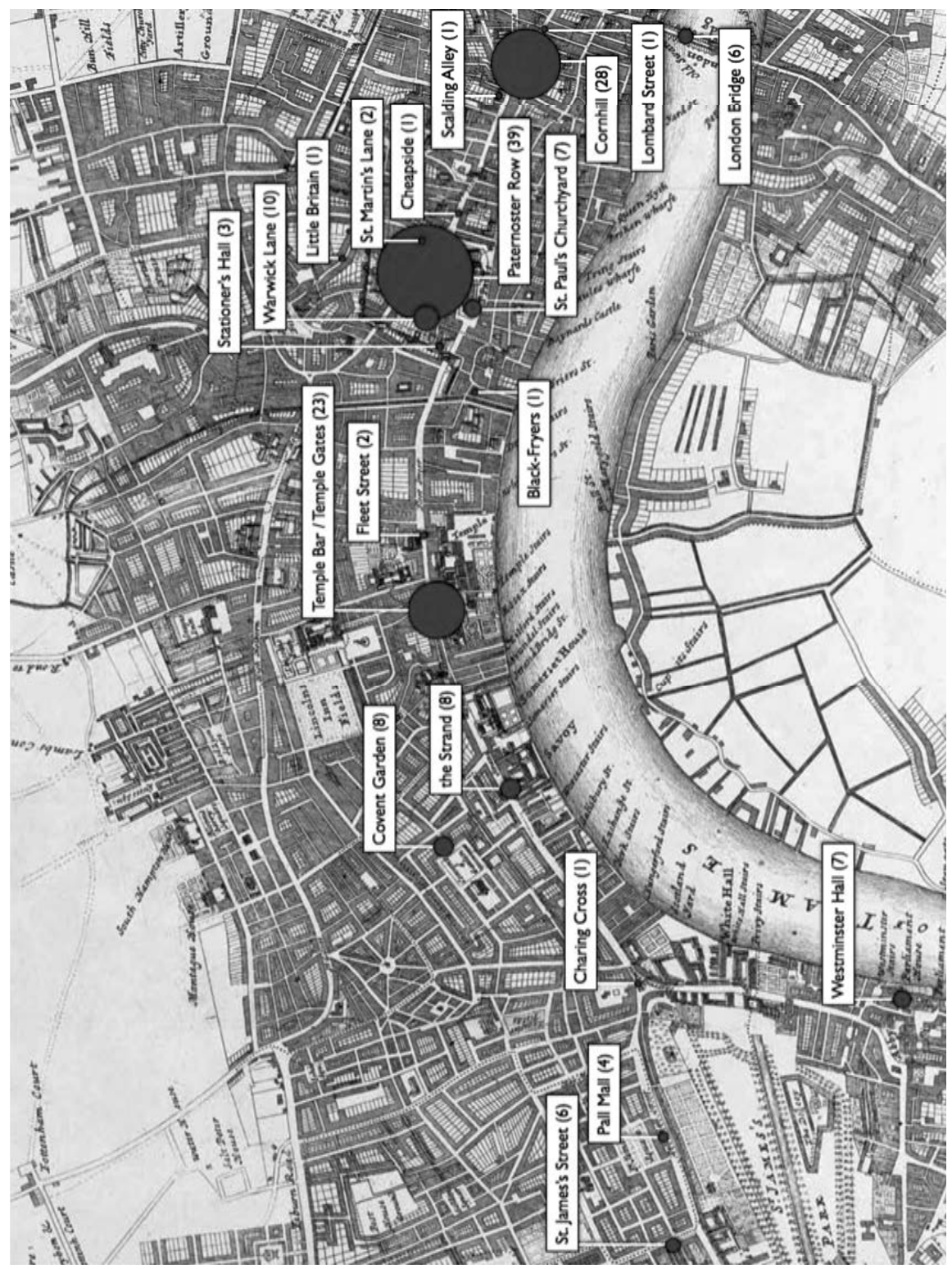

Figure 4. Daniel Defoe's booksellers in ESTC records for the decade up to publication of The Dunciad (1720-1727). 


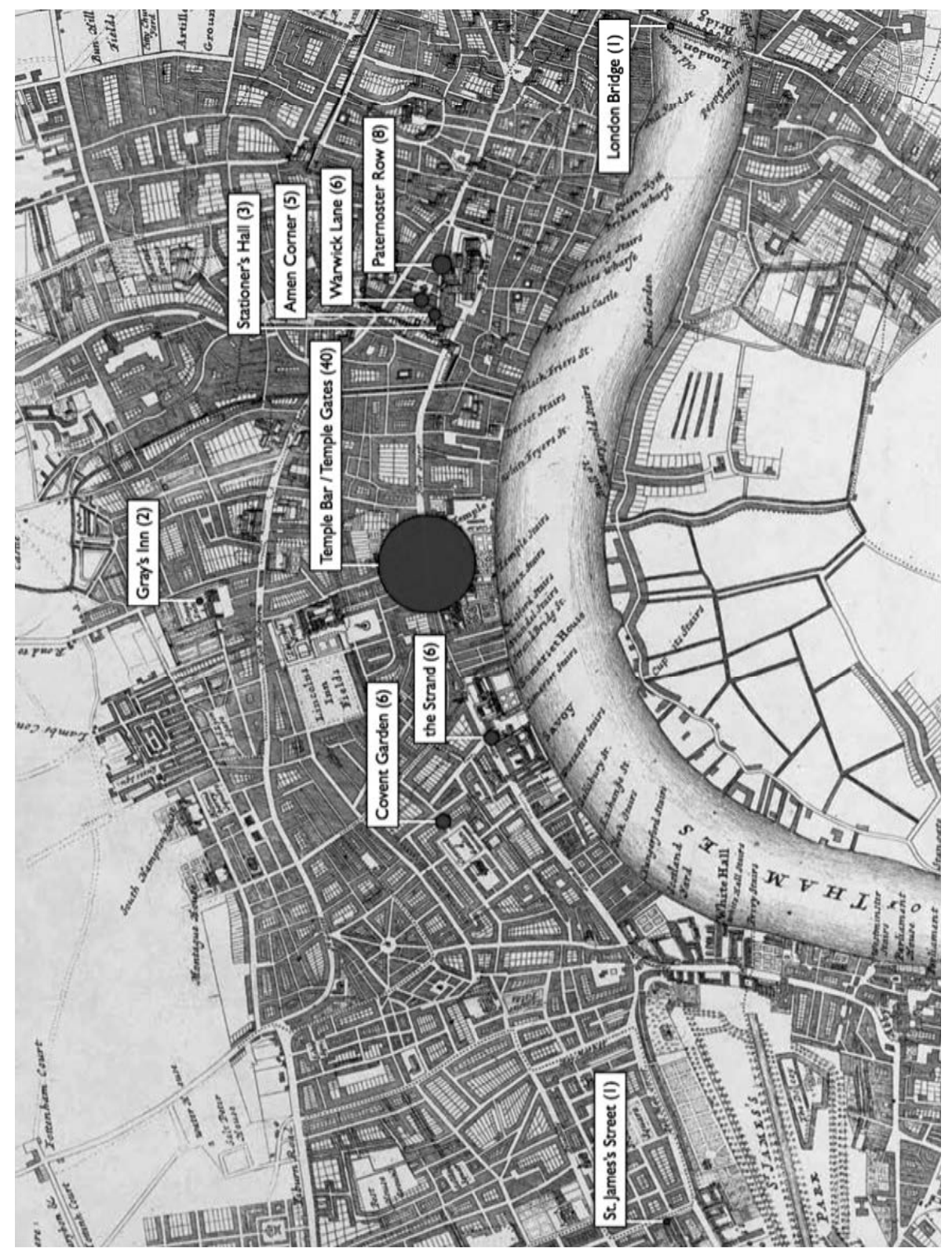

Figure 5. All Alexander Pope's booksellers in ESTC records up to the publication of The Dunciad (1709-1727). 


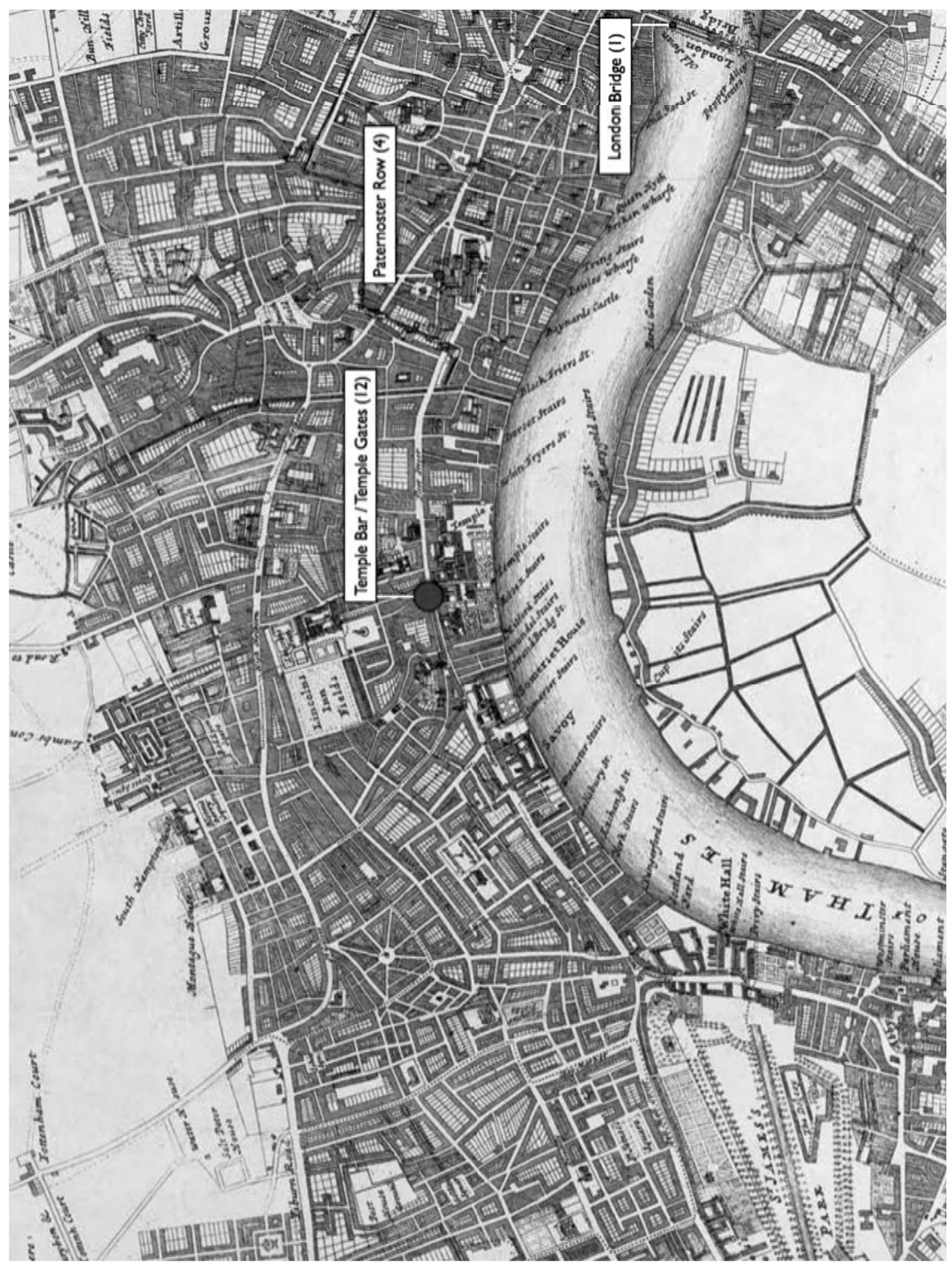

Alexander Pope's booksellers in ESTC records for the decade up to publication of The Dunciad (1720-1727). 